\title{
Gordonia araii sp. nov. and Gordonia effusa sp. nov., isolated from patients in Japan
}

\author{
Akiko Kageyama, ${ }^{1} \dagger$ Soji lida, ${ }^{1}$ Katsukiyo Yazawa, ${ }^{1}$ Takuji Kudo, ${ }^{2}$ \\ Shin-ichi Suzuki, ${ }^{3}$ Takeharu Koga, ${ }^{4}$ Hiromi Saito, ${ }^{5}$ Hiroko Inagawa, ${ }^{5}$ \\ Akihito Wada, ${ }^{6}$ Reiner M. Kroppenstedt ${ }^{7}$ and Yuzuru Mikami ${ }^{1}$ \\ ${ }^{1}$ Research Center for Pathogenic Fungi and Microbial Toxicoses, Chiba University, 1-8-1 \\ Inohana, Chuo-ku, Chiba 260-8673, Japan \\ 2Japan Collection of Microorganisms, RIKEN BioResource Center, Wako, Saitama 351-0198, \\ Japan \\ ${ }^{3}$ Discovery Research Laboratories, Tanabe Seiyaku Co. Ltd, 2-2-50 Kawagishi, Toda, Saitama \\ 335-8505, Japan \\ ${ }^{4}$ First Department of Internal Medicine, Kurume University School of Medicine, 67 Asahimachi, \\ Kurume 830-0011, Japan \\ ${ }^{5}$ Laboratory of Clinical Microbiology, Toranomon Hospital, Toranomon 2-2-2, Minato-ku, Tokyo \\ 105-8470, Japan \\ ${ }^{6}$ National Institute of Infectious Diseases, Toyama, Shinjuku-ku, Tokyo 162-8640, Japan \\ ${ }^{7}$ Deutsche Sammlung von Mikroorganismen und Zellkulturen, Braunschweig, Germany
}

Correspondence

Yuzuru Mikami

mikami@faculty.chiba-u.jp
Two bacterial strains, IFM $10211^{\top}$ and IFM $10200^{\top}$, were isolated from the sputum of two Japanese patients, and were subjected to a polyphasic taxonomic study. The two strains were found to have morphological, physiological and chemotaxonomic properties that were consistent with their assignment to the genus Gordonia, except for a few chemotaxonomic characteristics. Almost complete 16S rRNA gene sequences of the two strains were determined; the data showed that they are related distantly to Gordonia amarae, Gordonia hirsuta, Gordonia hydrophobica and Gordonia sihwensis, showing 16S rRNA gene sequence similarities to the type strains of these species of $96 \cdot 2-97 \cdot 9 \%$. DNA-DNA relatedness data coupled with the combination of genotypic and phenotypic data indicated that the two strains are representatives of two novel, separate species. The names proposed to accommodate these two strains are Gordonia araii sp. nov. (type strain IFM $10211^{\top}=\mathrm{DSM} 44811^{\top}=\mathrm{NBRC} 100433^{\top}=\mathrm{JCM} 12131^{\top}$ ) and Gordonia effusa sp. nov. (type strain IFM $10200^{\top}=\mathrm{DSM} 44810^{\top}=\mathrm{NBRC} 100432^{\top}=\mathrm{JCM} 12130^{\top}$ ).
The genus Gordonia belongs to the suborder Corynebacterineae within the order Actinomycetales (Stackebrandt et al., 1997). This suborder also contains the genera Corynebacterium, Dietzia, Mycobacterium, Nocardia, Skermania, Rhodococcus, Tsukamurella, Turicella and Williamsia (Goodfellow, 1998; Goodfellow et al., 1999; Kämpfer et al.,

†Present address: Kitasato Institute for Life Sciences, Kitasato University, 5-9-1, Shirokane, Minato-ku, Tokyo 108-8641, Japan.

Abbreviation: DAP, diaminopimelic acid.

The GenBank/EMBL/DDBJ accession number accession numbers for the $16 \mathrm{~S}$ rRNA gene sequences of Gordonia araii IFM $10211^{\top}$ and Gordonia effusa IFM $10200^{\top}$ are $\mathrm{AB} 162800$ and AB162799, respectively.

A table giving detailed physiological characteristics of members of the genus Gordonia is available as supplementary material in IJSEM Online.
1999). These genera are mutually distinguishable using a combination of biochemical, chemotaxonomic and morphological characteristics. The genus Gordonia was erected by Stackebrandt et al. (1988), and at the time of writing comprises 19 recognized species. Among them, Gordonia aichiensis, G. bronchialis, G. otitidis, G. sputi and G. terrae have been isolated from clinical specimens (Iida et al., 2005). G. bronchialis, Gordonia rubropertincta and G. sputi were specifically isolated from the sputum of patients with pulmonary disease (Klatte et al., 1994; Tsukamura, 1978).

Two hundred and thirty-five strains of pathogenic actinomycetes isolated from clinical specimens were referred to our research centre for identification during 2000-2003. Among these clinical specimens, strains IFM $10211^{\mathrm{T}}$ (in 2001) and IFM $10200^{\mathrm{T}}$ (in 2002) were isolated from sputum specimens of Japanese patients with kidney dysfunction and 
pulmonary disease, respectively. These organisms were found to be related to the genus Gordonia based on their phenotypic characteristics and TLC profile of mycolic acids. Furthermore, the two strains were found to cluster with the type strains of Gordonia amarae, G. hydrophobica, G. sihwensis and G. hirsuta based on 16S rRNA gene sequence analysis, but differences in several phenotypic characteristics and their genetic distinctiveness render them distinguishable. Comparative DNA-DNA relatedness data indicated that the strains belong to different species. Based on the phenotypic and genotypic data, we therefore suggest that the two clinical isolates represent two novel species of the genus Gordonia.

Strains IFM $10211^{\mathrm{T}}$ and IFM $10200^{\mathrm{T}}$ were isolated respectively from the sputum of a 48 -year-old male Japanese patient with bacterial pneumonia, and of a 74-year-old Japanese male patient with kidney dysfunction, and referred to our research centre for identification.

Strains IFM $10211^{\mathrm{T}}$ and IFM $10200^{\mathrm{T}}$ and reference strains $G$. amarae IFM $0210^{\mathrm{T}}$, G. hirsuta IFM $10287^{\mathrm{T}}$ and $G$. hydrophobica IFM $10286^{\mathrm{T}}$ were cultured on MuellerHinton II (MH II; Difco Laboratories) agar slants with $1 \%$ glucose and $1 \%$ glycerol for 1 week at $30^{\circ} \mathrm{C}$. For extraction of DNA and sequencing, bacterial strains were cultured in brain heart infusion (BHI; Difco Laboratories) broth containing $1 \%$ glucose for 4 days at $30^{\circ} \mathrm{C}$. For DNADNA hybridization experiments, strains were cultured in BHI broth containing $2 \%$ glucose and $2 \%$ glycine for 3 days at $30^{\circ} \mathrm{C}$. Micromorphological properties were observed by using electron microscopy according to a previously described method (Kageyama et al., 2004a). TLC analysis of mycolic acids for the differentiation of actinomycete genera containing these acids was performed according to the method of Miyadoh (2001). Carbon utilization tests were performed as described by Takeuchi \& Hatano (1998). The modified Ziehl-Neelsen method was used for the acidfast staining test. Whole-cell hydrolysates were analysed for diaminopimelic acid (DAP) isomers using TLC (Staneck \& Roberts, 1974). Whole-cell sugars were prepared as described by Lechevalier \& Lechevalier (1980) and analysed by TLC (Miyadoh, 2001). Methyl esters of cellular fatty acids mycolic acid trimethylsilyl esters were prepared and analysed as described by Klatte et al. (1994) using the standard Microbial Identification System (Microbial ID Inc.). Isoprenoid quinones were extracted by the method of Collins et al. (1977) and were analysed by HPLC with a Cosmosil $5 \mathrm{C}_{18}$ column $(4.6 \mathrm{~mm} \times 150 \mathrm{~mm}$; Nacalai Tesque Inc.). A mixture of methanol and 2-propanol $(2: 1, \mathrm{v} / \mathrm{v})$ was used as the elution solvent.

Preparation of genomic DNA samples for sequencing was performed using the guanidine thiocyanate method (Kageyama et al., 2004a, b).

The 16S rRNA gene was amplified and sequenced by PCR by employing six universal primers for the prokaryotic $16 \mathrm{~S}$ rRNA gene. We performed PCR with a DNA thermal cycler (TaKaRa) using 35 cycles consisting of denaturation at $94{ }^{\circ} \mathrm{C}$ for $60 \mathrm{~s}$, primer annealing at $60^{\circ} \mathrm{C}$ for $60 \mathrm{~s}$ and primer extension at $72^{\circ} \mathrm{C}$ for $120 \mathrm{~s}$. The PCR products were purified using a Centri-Sep column (Princeton Separations). DNA sequences were analysed with an automatic sequence analyser (ABI PRISM 3100; PE Applied Biosystems) by using a dye terminator cycle sequencing kit (PE Applied Biosystems).

A BLAST comparison of the 16S rRNA gene sequences of the two new isolates indicated that their closest neighbours were G. amarae, G. hydrophobica, G. sihwensis and G. hirsuta. Sequence data of related species were retrieved from GenBank. Nucleotide substitution rates ( $K_{\text {nuc }}$ values) were calculated (Kimura \& Ohta, 1972) and phylogenetic trees were constructed based on the neighbour-joining method (Saitou \& Nei, 1987). Tree topology was evaluated using a bootstrap analysis of sequence data with CLUSTAL W software (Thompson et al., 1994).

DNA was isolated using a modified method of that described by Saito \& Miura (1983). Levels of DNA-DNA relatedness were determined using the method of Ezaki et al. (1989) using photobiotin and microplates.

Whole-cell hydrolysates of strains IFM $10211^{\mathrm{T}}$ and IFM $10200^{\mathrm{T}}$ contained meso-DAP as the only diamino acid of the peptidoglycan and arabinose plus galactose as major whole-cell sugars (wall chemotype IV sensu Lechevalier \& Lechevalier, 1980). The fatty acid profiles of strains IFM $10200^{\mathrm{T}}$ and IFM $10211^{\mathrm{T}}$ consisted of straight-chain saturated and unsaturated fatty acids plus tuberculostearic acid, patterns similar to those of all genera in the suborder Corynebacterineae. The predominant menaquinone was MK-9 $\left(\mathrm{H}_{2}\right)$ for strain IFM $10211^{\mathrm{T}}$; strain IFM $10200^{\mathrm{T}}$ had MK-9 $\left(\mathrm{H}_{8}\right)$ and MK-9 $\left(\mathrm{H}_{6}\right)$, but also a small amount of MK$9\left(\mathrm{H}_{4}\right)$. These results were consistent with strain IFM $10211^{\mathrm{T}}$ belonging to the genus Gordonia, but no such conclusion could be made for strain IFM $10200^{\mathrm{T}}$ on this basis.

Strains IFM $10200^{\mathrm{T}}$ and IFM $10211^{\mathrm{T}}$ had mycolic acids with chain lengths of 62-70 and 58-64 carbons, respectively. The mycolic acid pattern of strain IFM $10211^{\mathrm{T}}$ thus differs from those of recognized Gordonia species, more closely resembling that of the genus Tsukamurella in the suborder Corynebacterineae. The pattern for strain IFM $10200^{\mathrm{T}}$ matched that of other members of the genus Gordonia.

Strains IFM $10211^{\mathrm{T}}$ and IFM $10200^{\mathrm{T}}$ produced short elementary branching hyphae that disintegrated into rodlike and cocci-like elements. Growth of strain IFM $10200^{\mathrm{T}}$ was faster than that of IFM $10211^{\mathrm{T}}$; no soluble pigment was produced in either strain. Almost complete $16 \mathrm{~S}$ rRNA gene sequences of strains IFM $10211^{\mathrm{T}}(1499 \mathrm{bp})$ and IFM $10200^{\mathrm{T}}$ (1509 bp) were determined. Phylogenetic analyses demonstrated that the two strains formed a monophyletic clade associated with G. amarae, G. hirsuta and G. hydrophobica (Fig. 1). On the basis of phylogenetic analysis, strains IFM $10211^{\mathrm{T}}$ and IFM $10200^{\mathrm{T}}$ were considered to belong to the genus Gordonia, but differences in the mycolic acid pattern of strain IFM $10211^{\mathrm{T}}$ and menaquinone composition of 


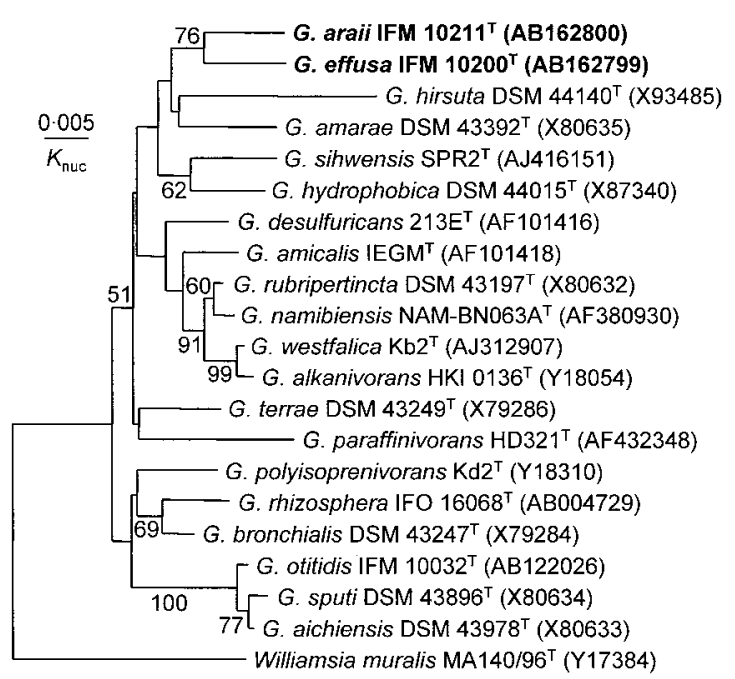

Fig. 1. Phylogenetic tree derived from 16S rRNA gene sequences, created using the neighbour-joining method (Saitou \& Nei, 1987) and $K_{\text {nuc }}$ values (Kimura \& Ohta, 1972). Numbers on the tree indicate bootstrap percentages (from 1000 replicates) for branch points. Only values $>50 \%$ are indicated. The tree was unrooted, using Williamsia muralis MA140-96 ${ }^{\top}$ as an outgroup.

strain IFM $10200^{\mathrm{T}}$ distinguished them from recognized species of the genus Gordonia. 16S rRNA gene sequence similarity between strains IFM $10211^{\mathrm{T}}$ and IFM $10200^{\mathrm{T}}$ was $97 \cdot 9 \%$; similarity values between strains IFM $10211^{\mathrm{T}}$ and IFM $10200^{\mathrm{T}}$ and their closest neighbour, G. amarae DSM $43392^{\mathrm{T}}$, were $97 \cdot 4$ and $97 \cdot 7 \%$, respectively. Lower levels of sequence similarity $(<97 \cdot 6 \%)$ were observed with the type strains of other neighbouring species, including $G$. hydrophobica and G. hirsuta (Table 1). The genomic delineation among strains IFM $10211^{\mathrm{T}}$ and IFM $10200^{\mathrm{T}}$ and the type strains of G. amarae, G. hydrophobica and G. hirsuta was supported by the DNA-DNA relatedness data (Table 1). The two new isolates showed levels of DNADNA relatedness of $6 \cdot 2-6 \cdot 9 \%$ to each other, and values in the range $3 \cdot 2-10 \cdot 9 \%$ to G. amarae, G. hydrophobica, G. hirsuta and G. sihwensis. These values are well below the
Table 2. Differential phenotypic properties among Gordonia species

Strains: 1, IFM $10211^{\mathrm{T}}$; 2, IFM $10200^{\mathrm{T}}$; 3, G. amarae DSM $44392^{\mathrm{T}} ; 4$, G. hirsuta DSM $44140^{\mathrm{T}} ; 5$, G. hydrophobica DSM $44015^{\mathrm{T}}$. Data were taken from Linos et al. (2002) and this study.

\begin{tabular}{|c|c|c|c|c|c|}
\hline Property & 1 & 2 & 3 & 4 & 5 \\
\hline \multicolumn{6}{|l|}{ Utilization of: } \\
\hline D-Galactose & - & - & + & + & + \\
\hline D-Ribose & + & - & + & - & - \\
\hline Sucrose & + & + & + & - & + \\
\hline D-Turanose & - & + & + & - & + \\
\hline myo-Inositol & - & - & - & + & - \\
\hline $\mathrm{N}$-Acetyl-D-glucosamine & - & + & - & - & - \\
\hline Glucarate & - & - & - & - & + \\
\hline Citrate & - & + & + & - & + \\
\hline 2-Oxoglutarate & - & - & + & + & - \\
\hline Succinate & - & + & - & - & + \\
\hline 4-Hydroxybenzoate & - & - & + & - & - \\
\hline Quinate & - & - & + & - & - \\
\hline L-Alanine & - & + & - & - & - \\
\hline L-Aspartate & - & + & - & - & - \\
\hline L-Leucine & - & - & - & - & + \\
\hline L-Valine & - & + & + & - & + \\
\hline Putrescine & + & + & + & - & - \\
\hline Acetamide & - & - & - & - & + \\
\hline
\end{tabular}

$70 \%$ cut-off point recommended for the delineation of genomic species (Wayne et al., 1987).

Strains IFM $10211^{\mathrm{T}}$ and IFM $10200^{\mathrm{T}}$ were also examined for a set of biochemical and physiological characteristics for comparison with those of other Gordonia species (Table 2). Both strains were readily distinguishable from these species based on a combination of physiological, biochemical and chemotaxonomic characteristics (see also Supplementary Table S1 available in IJSEM Online). They also differed phylogenetically from other Gordonia species (Fig. 1). Both phenotypic and genotypic data indicated that strains IFM $10211^{\mathrm{T}}$ and IFM $10200^{\mathrm{T}}$ represent two novel species of the genus Gordonia, for which we propose the names Gordonia araii sp. nov. and Gordonia effusa sp. nov., respectively.

Table 1. 16S rRNA gene sequence similarity and DNA-DNA relatedness between the isolated strains and related type strains

\begin{tabular}{|c|c|c|c|c|c|c|c|}
\hline \multirow[t]{2}{*}{ Strain } & \multicolumn{2}{|c|}{ 16S rRNA gene sequence similarity (\%) with: } & \multicolumn{5}{|c|}{ DNA-DNA hybridization (\%) with DNA from } \\
\hline & 1 & 2 & 1 & 2 & 3 & 4 & 5 \\
\hline 2. Strain IFM $10200^{\mathrm{T}}$ & $97 \cdot 9$ & $(100)$ & 7 & 100 & 3 & 5 & 5 \\
\hline 3. G. amarae IFM $0210^{\mathrm{T}}$ & $97 \cdot 4$ & $97 \cdot 7$ & 4 & 3 & 100 & 2 & 3 \\
\hline 4. G. hirsuta IFM $10287^{\mathrm{T}}$ & $96 \cdot 2$ & $96 \cdot 2$ & 4 & 4 & 1 & 100 & 4 \\
\hline
\end{tabular}




\section{Description of Gordonia araii sp. nov.}

Gordonia araii (a.rai'i. N.L. gen. n. araii of Arai, to honour Tadashi Arai, a Japanese microbiologist, for his valuable contributions to microbial taxonomy and secondary metabolites).

Aerobic, Gram-positive, slightly acid-fast, non-motile rods $(0 \cdot 3-0 \cdot 5 \times 0 \cdot 5-1 \cdot 1 \mu \mathrm{m})$. Colonies are white, becoming beige. Colonies are rough with irregular margins. No soluble pigment is produced. Colonies are $1 \cdot 5-3.5 \mathrm{~mm}$ in diameter after 7 days at $30^{\circ} \mathrm{C}$ on $\mathrm{MH}$ II medium. Utilizes glucose, but not adonitol, arabinose, erythritol, galactose, myo-inositol, maltose, mannose or sorbitol. Adenine, hypoxanthine, tyrosine, urea and xanthine are not hydrolysed. Contains meso-DAP, arabinose and galactose (cell wall chemotype IV sensu Lechevalier \& Lechevalier, 1980). Predominant menaquinone is MK- $9\left(\mathrm{H}_{2}\right)$. Major fatty acids are $\mathrm{C}_{14: 0}$, $\mathrm{C}_{16: 1}$ cis-9, $\mathrm{C}_{16: 0}, \mathrm{C}_{18: 1}$ cis-9, $\mathrm{C}_{18: 0}$ and 10-methyl $\mathrm{C}_{18: 0}$. Mycolic acids are present with a range of total carbon number from 64 to 70 .

The type strain, IFM $10211^{\mathrm{T}}\left(=\mathrm{DSM} 44811^{\mathrm{T}}=\mathrm{NBRC}\right.$ $100433^{\mathrm{T}}=\mathrm{JCM} 12131^{\mathrm{T}}$ ), was isolated from a clinical specimen.

\section{Description of Gordonia effusa sp. nov.}

Gordonia effusa (ef.fu'sa. L. fem. adj. effusa poured out, extensive, vast, broad, wide, referring to the spreading colonial growth).

Aerobic, Gram-positive, slightly acid-fast, non-motile rods $(0 \cdot 3-0 \cdot 6 \times 0 \cdot 5-2 \cdot 1 \mu \mathrm{m})$. Colonies are white, becoming beige. Colonies are rough with irregular margins. No soluble pigment is produced. Colonial growth is fast; colony diameter is $3 \cdot 0-5 \cdot 0 \mathrm{~mm}$ after 7 days at $30^{\circ} \mathrm{C}$ on $\mathrm{MH}$ II medium. Utilizes sucrose, D-turanose, $\mathrm{N}$-acetyl-D-glucosamine, citrate, 4-aminobutyrate, succinate, L-alanine, Laspartate, L-valine and putrescine, but not D-galactose, L-rhamnose, D-ribose, D-arabitol or myo-inositol. Contains meso-DAP, arabinose and galactose (cell wall chemotype IV sensu Lechevalier \& Lechevalier, 1980). Predominant menaquinones are MK-9 $\left(\mathrm{H}_{8}\right)$ and MK-9 $\left(\mathrm{H}_{6}\right)$; a small amount of MK- $9\left(\mathrm{H}_{4}\right)$ is also present. Major fatty acids are $\mathrm{C}_{14: 0}, \mathrm{C}_{15: 0}, \mathrm{C}_{16: 0}, \mathrm{C}_{17: 0}, \mathrm{C}_{18: 0}$ and 10-methyl $\mathrm{C}_{18: 0}$. Mycolic acids are present with a range of total carbon number from 60 to 64 .

The type strain, IFM $10200^{\mathrm{T}}\left(=\mathrm{DSM} 44810^{\mathrm{T}}=\mathrm{NBRC}\right.$ $100432^{\mathrm{T}}=\mathrm{JCM} 12130^{\mathrm{T}}$ ), was isolated from a clinical specimen.

\section{References}

Collins, M. D., Prouz, T., Goodfellow, M. \& Minikkin, D. E. (1977). Distribution of menaquinones in actinomycetes and corynebacteria. $J$ Gen Microbiol 100, 221-230.

Ezaki, T., Hashimoto, Y. \& Yabuuchi, E. (1989). Fluorometric deoxyribonucleic acid-deoxyribonucleic acid hybridization in microdilution wells as an alternative to membrane filter hybridization in which radioisotopes are used to determine genetic relatedness among bacterial strains. Int J Syst Bacteriol 39, 224-229.

Goodfellow, M. (1998). Nocardia and related genera. In Topley and Wilson's Microbiology and Microbial Infections, 9th edn, vol. 2, Systematic Bacteriology, pp. 463-489. Edited by A. Balows \& B. I. Duerden. London: Arnold.

Goodfellow, M., Isik, K. \& Yates, E. (1999). Actinomycete systematics: an unfinished synthesis. Nova Acta Leopold NF80 (312), 47-82.

lida, S., Taniguchi, H., Kageyama, A., Yazawa, K., Chibana, H., Murata, S., Nomura, F., Kroppenstedt, R. M. \& Mikami, Y. (2005). Gordonia otitidis sp. nov., isolated from a patient with external otitis. Int J Syst Evol Microbiol 55, 1871-1876.

Kageyama, A., Torikoe, K., Iwamoto, M. \& 7 other authors (2004a). Nocardia arthritidis sp. nov., a new pathogen isolated from a patient with rheumatoid arthritis in Japan. J Clin Microbiol 42, 2366 2371.

Kageyama, A., Poonwan, N., Yazawa, K., Mikami, Y. \& Nishimura, K. (2004b). Nocardia asiatica sp. nov. isolated from patients with nocardiosis in Japan and clinical specimens from Thailand. Int J Syst Evol Microbiol 54, 125-130.

Kämpfer, P., Andersson, M. A., Rainey, F. A., Kroppenstedt, R. M. \& Salkinoja-Salonen, M. (1999). Williamsia muralis gen. nov., sp. nov., isolated from the indoor environment of a children's day care centre. Int J Syst Bacteriol 49, 681-687.

Kimura, M. \& Ohta, T. (1972). On the stochastic model for estimation of mutation distance between homologous proteins. $J \mathrm{Mol}$ Evol 2, 87-90.

Klatte, S., Rainey, F. A. \& Kroppenstedt, R. M. (1994). Transfer of Rhodococcus aichiensis Tsukamura 1982 and Nocardia amarae Lechevalier and Lechevalier 1974 to the genus Gordona as Gordona aichiensis comb. nov. and Gordona amarae comb. nov. Int J Syst Bacteriol 44, 769-773.

Lechevalier, M. P. \& Lechevalier, H. A. (1980). The chemotaxonomy of actinomycetes. In Actinomycete Taxonomy, pp. 227-291. Edited by A. Dietz \& D. W. Thayer. Fairfax, VA: Society for Industrial Microbiology.

Linos, A., Berekaa, M. M., Steinbüchel, A., Kim, K. K., Spröer, C. \& Kroppenstedt, M. (2002). Gordonia westfalica sp. nov., a novel rubber-degrading actinomycete. Int J Syst Evol Microbiol 52, 1133 1139.

Miyadoh, M. (2001). Identification procedure at the genus level. In Identification Manual of Actinomycetes, pp. 9-19. Edited by S. Miyadoh, M. Hamada, K. Hotta, T. Kudo, A. Seino, K. Suzuki \& A. Yokota. Tokyo: Business Center for Academic Societies Japan.

Saito, H. \& Miura, K. (1983). Preparation of transforming deoxyribonucleic acid by phenol treatment. Biochim Biophys Acta 72, 619-629.

Saitou, N. \& Nei, M. (1987). The neighbor-joining method: a new method for reconstructing phylogenetic trees. Mol Biol Evol 4, 406425 .

Stackebrandt, E., Smida, J. \& Collins, M. D. (1988). Evidence of phylogenetic heterogeneity within the genus Rhodococcus: revival of the genus Gordona (Tsukamura). J Gen Appl Microbiol 34, 341348.

Stackebrandt, E., Rainey, F. A. \& Ward-Rainey, N. L. (1997). Proposal for a new hierarchic classification system, Actinobacteria class nov. Int J Syst Bacteriol 47, 479-491.

Staneck, J. L. \& Roberts, G. D. (1974). Simplified approach to identification of aerobic actinomycetes by thin-layer chromatography. Appl Microbiol 28, 226-231. 
Takeuchi, M. \& Hatano, K. (1998). Gordonia rhizosphera sp. nov. isolated from the mangrove rhizosphere. Int J Syst Bacteriol 48, 907912.

Thompson, J. D., Higgins, D. G. \& Gibson, T. J. (1994). CLUSTAL W: improving the sensitivity of progressive multiple sequence alignment through sequence weighting, position-specific gap penalties and weight matrix choice. Nucleic Acids Res 22, 4673-4680.
Tsukamura, M. (1978). Numerical classification of Rhodococcus (formerly Gordona) organisms recently isolated from sputa of patients; description of Rhodococcus sputi Tsukamura sp. nov. Int J Syst Bacteriol 28, 169-181.

Wayne, L. G., Brenner, D. J., Colwell, R. R. \& 9 other authors (1987). Report of the ad hoc committee on reconciliation of approaches to bacterial systematics. Int J Syst Bacteriol 37, 463-464. 